\title{
IMPLEMENTASI MEDIA PEMBELAJARAN SIMULATOR BASIC PNEUMATIC PADA MATA KULIAH PNEUMATIK HIDROLIK
}

\author{
Ngatou Rohman \\ Program Studi Pendidikan Teknik Mesin JPTK FKIP UNS, \\ ngatourohman@fkip.uns.ac.id
}

\begin{abstract}
ABSTRAK
Metodologi pembejaran memiliki memiliki dua aspek yaitu metode mengajar dan media pembelajaran yang digunakan oleh guru/dosen di dalam kelas. Sebagai alat bantu pembelajaran, peran dan fungsi media pembelajaran tidak boleh diremehkan. Sebab proses pembelajaran yang berkualitas selalu menyediakan sumber belajar dan atau media pembelajaran yang kaya dan bervariasi. Media pembelajaran yang kaya dan bervariasi tidak saja membuat motivasi belajar meningkat, tetapi juga menjadikan hasil belajar lebih bermakna atau berkualitas. Dari hasil pengamatan diperoleh gambaran bahwa sebagian besar mahasiswa memiliki kesulitan dalam memahami konsep mengenai katup kontrol dan katup kerja pada sistem pneumatik dan hidrolik. . Salah satu jenis media yang dianggap sesuai untuk mengatasi permasalahan di atas adalah menggunakan media simulator basic pneumatic yang merupakan hasil kreatifitas mahasiswa yang menempuh mata kuliah karya inovatif. penelitian termasuk penelitian deskriptif dengan kategori penelitian eksperimen. Hal ini dikarenakan diberikan perlakuan (penggunaan media pembelajaran dalam bentuk simulator basic pneumatic) pada mahasiswa untuk meningkatkan kualitas pembelajaran yang meliputi hasil belajar dan keaktifan belajar dalam mengikuti perkuliahan pneumatik hidrolik. Penelitian ini juga termasuk penelitian eksperimen semu (quasi exsperimen) jenis " the one-shot case study". Lokasi penelitian ini dilaksanakan di Program Studi Pendidikan Teknik Mesin JPTK FKIP UNS semester genap TA 2011/2012. Subjek penelitian ini adalah mahasiswa yang menempuh mata kuliah Pneumatik Hidrolik dengan jumlah 57 mahasiswa. Teknik analisis data hasil penelitian dilakukan dengan cara menganalisis data hasil tes dan pengamatan. Berdasarkan hasil penelitian dan pembahasan dapat disimpulkan penggunaan media pembelajaran dalam bentuk simulator basic pneumatik memiliki pengaruh yang positif terhadap kualitas perkuliahan pada mata kuliah Pneumatik Hidrolik. Meningkatnya kulaitas perkuliahan ditunjukkan dengan dua hal yaitu hasil belajar dan keaktifan mahasiswa dalam proses pembelajaran/perkuliahan.
\end{abstract}

Kata kunci: media pembelajaran, basic pneumatik, hasil belajar

\section{PENDAHULUAN}

Pada hakekatnya proses pendidikan baik formal, non formal maupun informal merupakan upaya mempersiapkan atau membekali sumber daya manusia (SDM) yang memiliki kemampuan atau kompetensi sesuai dengan perubahan tantangan kehidupan. FKIP merupakan salah satu Lembaga Pendidik dan Tenaga Kependidikan (LPTK) yang bertujuan untuk mencetak lulusan (calon guru) yang berkualitas, inovatif dan responsif dalam mengahadapi permasalahanpermasalahan yang terkait dengan pendidikan secara umum dan lebih khusus pada proses pembelajaran.

Tujuan pendidikan dapat tercapai apabila proses pembelajaran yang dilaksanakan di FKIP mengacu kepada empat aspek kompetensi guru yaitu (1) kompetensi pedagogik, (2) kompetensi kepribadian, (3) kompetensi profesional, dan (4) kompetensi sosial. Secara khusus FKIP menekankan pada penguasaan bidang studi sebagai implementasi dari kompetensi profesional dan kemampuan di bidang kependidikan, kurikulum FKIP diharapkan dapat menghasilkan lulusan yang mampu: (1) memahami konsep ilmunya, (2) menggunakan metode dan media yang diperlukan untuk memahamai ilmunya, (3) memahami kaitan antara berbagai konsep dalam ilmunya dan ilmu lain, (4) memahami ciri-ciri dan perkembangan peserta didik, (5) memahami konsep dasar tentang pendidikan dan proses belajar mengajar, (6) memiliki komitmen dan selalu meningkat profesional dan memiliki kepekaan sosial yang tinggi dan aktif dalam upaya pemecahan masalah sosial kemasyarakat.

Program Studi Pendidikan Teknik Mesin JPTK FKIP UNS merupakan salah satu Lembaga Pendidikan Tenaga Kependidikan (LPTK) yang bertujuan menghasilkan calon guru yang kompeten dalam bidang pemesinan dan otomotif. Dalam kontek pembelajaran Program Studi Pendidikan Teknik Mesin JPTK FKIP UNS memberikan bekal kompetensi kepada mahasiswa agar dapat menguasai konsep pendidikan, mengaitkan antar konsep pendidikan, memahami peserta didik, konsep pendidikan dan pembelajaran, serta menekankan pada 
keterampilan pemecahan masalah pendidikan. Kualitas proses pembelajaran akan dipengaruhi oleh berbagai macam faktor baik yang berasal dari internal maupun eksternal. Hal-hal yang terkait dengan internal proses pembelajaran misalnya: kurikulum, guru, siswa, sarana prasarana dan metodologi pembelajaran. Sedangkan hal yang terkait dengan eksternal proses pembelajaran misalnya suasana lingkungan sekolah, lingkungan masyarakat sekitar sekolah dan peran orang tua. Masingmasing faktor tersebut tentu saling memiliki keterkaitan satu sama lain, artinya kualitas pembelajaran atau perkuliahan sangat tergantung dari peran faktor-faktor tersebut.

Pengelolaan pembelajaran/perkuliahan didalam kelas sangat dipengaruhi oleh metodologi pembelajaran yang diterapkan oleh guru/dosen. Metodologi pembejaran memiliki memiliki dua aspek yaitu metode mengajar dan media pembelajaran yang digunakan oleh guru/dosen di dalam kelas. Sebagai alat bantu pembelajaran, peran dan fungsi media pembelajaran tidak boleh diremehkan. Sebab proses pembelajaran yang berkualitas selalu menyediakan sumber belajar dan atau media pembelajaran yang kaya dan bervariasi. Media pembelajaran yang kaya dan bervariasi tidak saja membuat motivasi belajar meningkat, tetapi juga menjadikan hasil belajar lebih bermakna atau berkualitas.

Mata kuliah Pneumatik Hidrolik merupakan salah satu mata kuliah wajib yang harus ditempuh oleh mahasiswa Program Studi Pendidikan Teknik Mesin JPTK FKIP UNS. Mata kuliah Pneumatik Hidrolik memiliki bobot 2 SKS dan dalam struktur kurikulum yang digunakan oleh Program Studi Pendidikan Teknik Mesin JPTK FKIP UNS terdapat pada semester IV. Mata kuliah Pneumatik Hidrolik ini mempelajari tentang konsep dasar, prinsip kerja, simbol-simbol dan mekanisme katup kontrol pada sistem pneumatik dan hidrolik. Dari hasil pengamatan diperoleh gambaran bahwa sebagian besar mahasiswa memiliki kesulitan dalam memahami konsep mengenai katup kontrol dan katup kerja pada sistem pneumatik dan hidrolik. Kesulitan mahasiswa tentang katup kontrol dan katup kerja ini dapat terlihat dari hasil nilai uji kompetensi untuk kompetensi dasar katup kontrol dan katup kerja yang sebagian besar $(60 \%)$ mahasiswa memperoleh nilai C. Pada saat mengkaji materi yang terkait dengan sistem pneumatik dan hidrolik dosen lebih banyak menggunakan media pembelajaran gambar diam dan animasi.

Untuk mengatasi persoalan di atas, dosen perlu menumbuhkembangkan kemampuan mahasiswa agar mampu menguasai konsep dan terampil memecahkan masalah yang terkait dengan katup kontrol, katup kerja sistem pneumatik hidrolik. Salah satu jenis media yang dianggap sesuai untuk mengatasi permasalahan di atas adalah menggunakan media simulator basic pneumatic yang merupakan hasil kreatifitas mahasiswa yang menempuh mata kuliah karya inovatif. Media simulator ini didesain untuk pembejaran mengingat konstruksinya yang ringkas dan memungkinkan untuk dibawa ke dalam ruang kuliah.

Harapan penggunaan media pembejaran simulasi basic pneumatic yaitu meningkatkan kualitas perkuliahan yang ditunjukkan dengan meningkatnya hasil belajar dan keaktifan belajaran mahasiswa untuk kompetensi dasar katup kontrol dan katup kerja pada mata kuliah pneumatik hidrolik.

\section{LANDASAN TEORI}

Kata media berasal dari bahasa latin medius yang secara harfiah berarti 'tengah', 'perantara' atau 'pengantar'. Gerlach \& Ely (1971) mengatakan bahwa media apabila dipahami secara garis besar adalah manusia, materi, atau kejadian yang membangun kondisi yang membuat siswa mampu memperoleh pengetahuan, keterampilan, atau sikap. Secara lebih khusus, pengertian media dalam proses belajar mengajar cenderung diartikan alat-alat grafis, fotografis, atau elektronis untuk menangkap, memproses, dan menyusun kembali informasi visual dan verbal.

Media adalah alat bantu apa saja yang dapat dijadikan sebagai penyalur pesan guna mencapai tujuan pengajaran (Djamarah, 2002: 137). Sedangkan pembelajaran adalah proses, cara, perbuatan yang menjadikan orang atau makhluk hidup belajar (Kamus Besar Bahasa Indonesia, 2002: 17). Jadi, media pembelajaran adalah media yang digunakan pada proses pembelajaran sebagai penyalur pesan antara guru dan siswa agar tujuan pengajaran tercapai.

Secara umum, manfaat media dalam proses pembelajaran adalah memperlancar interaksi antara guru dan siswa sehingga kegiatan pembelajaran akan lebih efektif dan efisien. Tetapi secara khusus ada beberapa manfaat media yang lebih rinci. Kemp dan Dayton (dalam 
Depdiknas, 2003) mengidentifikasikan beberapa manfaat media dalam pembelajaran yaitu:

1. Penyampaian materi pelajaran dapat diseragamkan.

2. Proses pembelajaran menjadi lebih jelas dan menarik.

3. Proses pembelajaran menjadi lebih interaktif.

4. Efisiensi dalam waktu dan tenaga.

5. Meningkatkan kualitas hasil belajar siswa.

6. Media memungkinkan proses belajar dapat dilakukan di mana saja dan kapan saja.

7. Media dapat menumbuhkan sikap positif siswa terhadap materi dan proses belajar.

8. Mengubah peran guru ke arah yang lebih positif dan produktif.

Menurut Oemar Hamalik (1985:63) ada empat klasifikasi media pengajaran yaitu:

1. Alat-alat visual yang dapat dilihat.

2. Alat-alat yang bersifat auditif atau hanya dapat didengar.

3. Alat-alat yang bisa dilihat dan didengar.

4. Dramatisasi, bermain peranan, sosiodrama, sandiwara boneka, dan sebagainya.

Simulasi merupakan tiruan dari proses operasi dunia nyata. Simulasi juga digunakan untuk menggambarkan dan menganalisa perilaku sebuah sistem, mengetahui what-if questions tentang sistem riil dan membantu merancang sistem riil $^{[3]}$. Simulasi dapat digunakan sebagai metoda pembelajaran dengan asumsi tidak semua proses pembelajaran dapat dilakukan secara langsung pada objek sebenarnya.

Metoda simulasi adalah bentuk metoda praktik yang sifatnya untuk mengembangkan keterampilan siswa. Metoda ini memindahkan suatu situasi yang nyata ke dalam ruang belajar. Metoda simulasi digunakan karena tidak memungkinkan melakukan praktik secara nyata. Tujuan dari penggunaan metoda simulasi adalah sebagai berikut: (1) melatih keterampilan tertentu baik bersifat professional maupun bagi kehidupan sehari-hari; (2) memperoleh pemahaman tentang suatu konsep atau prinsip; (3) melatih memecahkan masalah; (4) meningkatkan keaktifan belajar; (5) memberikan motivasi belajar kepada siswa; (6) melatih siswa untuk mengadakan kerjasama dalam situasi kelompok; (7) menumbuhkan daya kreatif siswa; (8) melatih siswa untuk mengembangkan sikap toleransi.
Menurut Nana Sudjana (2005: 3) hakikat hasil belajar adalah perubahan tingkah laku individu yang mencakup aspek kognitif, afektif, dan psikomotorik. Menurut Nana Sudjana (1989: 38-40) hasil belajar yang dicapai siswa dipengaruhi oleh dua faktor utama yakni faktor dari dalam diri siswa itu dan faktor yang datang dari luar diri siswa atau faktor lingkungan. Faktor yang datang dari diri siswa terutama kemampuan yang dimilikinya. Faktor kemampuan siswa besar sekali pengaruhnya terhadap hasil belajar yang dicapai. Disamping faktor kemampuan yang dimiliki siswa, juga ada faktor lain, seperti motivasi belajar, minat dan perhatian, sikap dan kebiasaan belajar, ketekunan, sosial ekonomi, faktor fisik dan psikis.

Hasil belajar merupakan segala upaya yang menyangkut aktivitas otak (proses berfikir) terutama dalam ranah kognitif, afektif, dan psikomotorik. Proses berfikir ini ada enam jenjang, mulai dari yang terendah sampai dengan jenjang tertinggi (Suharsimi Arikunto, 2003: 114115). Keenam jenjang tersebut adalah: (1) Pengetahuan (knowledge) yaitu kemampuan seseorang untuk mengingat kembali tentang nama, istilah, ide, gejala, rumus- rumus dan lain sebagainya, tanpa mengharapkan kemampuan untuk menggunakannya. (2) Pemahaman (comprehension) yakni kemampuan seseorang untuk memahami sesuatu setelah sesuatu itu diketahui dan diingat melalui penjelasan dari kata- katanya sendiri. (3) Penerapan (application) yaitu kesanggupan seseorang untuk menggunakan ide- ide umum, tata cara atau metode- metode, prinsip- prinsip, rumus- rumus, teori- teori, dan lain sebagainya dalam situasi yang baru dan kongkret. (4) Analisis (analysis) yakni kemampuan seseorang untuk menguraikan suatu bahan atau keadaan menurut bagian- bagian yang lebih kecil dan mampu memahami hubungan diantara bagian- bagian tersebut. (5) Sintesis (synthesis) adalah kemampuan berfikir memadukan bagian- bagian atau unsur- unsur secara logis, sehingga menjadi suatu pola yang baru dan terstruktur. (6) Evaluasi (evaluation) yang merupakan jenjang berfikir paling tinggi dalam ranah kognitif menurut Taksonomi Bloom.

\section{METODE PENELITIAN}

Sesuai dengan tujuan penelitian yang ingin dicapai, jenis penelitian termasuk penelitian deskriptif dengan kategori penelitian eksperimen. Hal ini dikarenakan diberikan perlakuan (penggunaan media pembelajaran dalam bentuk 
simulator basic pneumatic) pada mahasiswa untuk meningkatkan kualitas pembelajaran yang meliputi hasil belajar dan keaktifan belajar dalam mengikuti perkuliahan pneumatik hidrolik. Penelitian ini juga termasuk penelitian eksperimen semu (quasi exsperimen) jenis " the one-shot case study" dengan rancangan penelitian sebagai berikut:

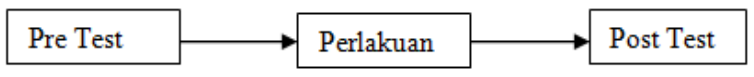

Gambar 1. Rancangan Penelitian

Lokasi penelitian ini dilaksanakan di Program Studi Pendidikan Teknik Mesin JPTK FKIP UNS semester genap TA 2011/2012. Subjek penelitian ini adalah mahasiswa yang menempuh mata kuliah Pneumatik Hidrolik dengan jumlah 57 mahasiswa. Instrumen dan teknik pengumpulan data yang digunakan dalam penelitian ini sebagai berikut:

1. Instrumen tes yaitu tes awal (pre test) dan tes akhir (post test). Instrumen tes awal ini digunakan untuk mendapatkan data kemampuan awal mahasiswa dalam memahami konsep katup kontrol dan katup kerja pada sistem pneumatik dan hidrolik. Tes awal dilaksanakan sebelum penggunaan media pembelajaran simulasi basic pneumatic. Sedangkan instrumen tes akhir digunakan untuk mendapatkan data kemampuan mahasiswa dalam memahami konsep katup kontrol dan katup kerja pada sistem pneumatik dan hidrolik setelah penggunaan media pembelajaran simulasi basic pneumatic. Soal tes berbentuk essay dan berjumlah 4 soal dengan waktu 90 menit.

2. Lembar observasi aktivitas mahasiswa

Lembar observasi aktivitas mahasiswa ini digunakan untuk mendapatkan data aktivitas mahasiswa selama pembelajaran berlangsung. Lembar observasi aktivitas mahasiswa diisi oleh seorang pengamat dengan cara menuliskan cek list (V) sesuai dengan keadaan yang diamati.

Teknik analisis data hasil penelitian dilakukan dengan cara sebagai berikut:

1. Data hasil tes. Setelah tes dilaksanakan selanjutnya lembar jawaban mahasiswa di koreksi dan diberikan skor sesuai pedoman penskoran yang telah ditetapkan. Pedoman skor yang digunakan menggunakan acuan $\mathrm{A}$,
$\mathrm{B}, \mathrm{C}, \mathrm{D}$ dan $\mathrm{E}$ melalui konversi nilai skala 100.

2. Data aktivitas mahasiswa. Data ini dianalisis secara deskriptif dengan cara menghitung skor rata-rata dari setiap aspek yang diamati.

\section{HASIL DAN PEMBAHASAN}

1. Deskripsi Hasil Kegiatan Awal Penelitian Sebelum pelaksanaan eksperimen, diawali dengan pelaksanaan tes awal (pre test). Tes awal ini digunakan untuk memperoleh data kemampuan awal mahasiswa dalam memahami konsep katup kontrol dan katup kerja pada sistem pneumatik dan hidrolik. Tes awal ini diikuti 55 orang mahasiswa dari 57 orang mahassiwa sedangkan 2 orang mahasiswa keadaan sakit. Hasil tes ini dijadikan sebagai salah satu acuan dalam menganalisa dampak dari perlakuan atau treatment penggunaan simulator basic pneumatic.

2. Deskripsi Pelaksanaan Perlakuan

Dalam pelaksanaan treatment penggunaan simulator basic pneumatic pada mata kuliah Pneumatik Hidrolik dilaksanakan dalam 4 kali pertemuan dengan rincian: pertemuan pertama digunakan untuk tes awal. Pertemuan kedua, ketiga dan keempat pembelajaran tentang katup kontrol dan katup kerja pada sistem pneumatik dan hidrolik dengan menggunakan media pembelajaran simulator basic pneumatic. Pertemuan kelima digunakan untuk uji kompetensi, hasil uji kompetensi tersebut juga dijadikan sebagai data post test ( pasca perlakuan) yang kemudian dideskripsikan untuk dianalisis. Pada saat pelaksanaan perlakuan ini, dosen pengampu dibantu oleh 1 orang observer untuk mengamati keaktifan mahasiswa selama perkuliahan pada tatap muka yang menggunakan media simulator. Observer tersebut mengamati aktifitas belajar mahasiswa dengan menggunakan acuan lembar observasi yang telah dibuat meliputi: keaktifan menyampaikan pertanyaan, menyampaikan pendapat, menjawab pertanyaan, sharing dengan teman sejawat.

\section{Deskripsi Pelaksanaan Tes Akhir Perlakuan (Post Test)}

Tes akhir perlakuan (post test) dilaksanakan setelah proses pembelajaran berlangsung selama 2 pertemuan. Post test diikuti oleh 57 orang mahasiswa, namun data yang digunakan untuk analisis hanya berjumlah 55 sesuai dengan data pada saat pre test. Nilai hasil uji kompetensi 2 orang mahasiswa yang tidak mengikuti pre test tetap digunakan namun dalam kontek akademik. 
Tabel 1. Rekapitulasi Hasil Pre Test dan Post Test

\begin{tabular}{ccccc}
\hline & \multicolumn{2}{c}{ Hasil Belajar (Pre } \\
Test) & \multicolumn{2}{c}{$\begin{array}{c}\text { Hasil } \\
\text { Kelompok } \\
\text { Nilai }\end{array}$} & \multicolumn{2}{c}{$\begin{array}{c}\text { Jaj (Post } \\
\text { Test) }\end{array}$} \\
\cline { 2 - 5 } & Jumlah & Persentase & Jumlah & $\begin{array}{c}\text { Persen } \\
\text { tase }\end{array}$ \\
\hline A & 5 & 9 & 15 & 27 \\
B & 12 & 22 & 28 & 51 \\
C & 35 & 64 & 12 & 22 \\
D & 3 & 5 & 0 & 0 \\
E & 0 & 0 & 0 & 0 \\
\hline
\end{tabular}

Berdasarkan tabel di atas, diperoleh gambaran bahwa ada kenaikan jumlah prosentase mahasiswa yang memperoleh nilai A dari 5 orang mahasiswa $(9 \%)$ pada saat pre test menjadi 15 orang mahasiswa $(27 \%)$ pada saat dilaksanakan post test. Jumlah mahasiswa yang memperoleh nilai B meningkat dari 12 orang mahasiswa (22\%) saat pre test menjadi 28 orang mahasiswa (51\%) saat post test. Jumlah mahasiswa yang memperoleh nilai $\mathrm{C}$ berkurang dari 35 orang mahasiswa (64\%) saat pre test menjadi 12 orang mahasiswa $(22 \%)$ saat post test. Penurunan jumlah mahasiswa yang memperoleh nilai $C$ disini menunjukkan adanya adanya dampak positif. Jumlah mahasiswa yang memperoleh nilai $\mathrm{D}$ berkurang dari 3 orang mahasiswa $(5 \%)$ saat pre test menjadi $0(0 \%)$ saat post test.

4. Keaktifan Mahasiswa

Dari hasil pengamatan yang dilakukan oleh dosen pengampu dan dibantu oleh observer dapat dideskripsikan data tentang keaktifan belajar mahasiswa sebagai berikut:

Tabel 2. Data Keaktifan Mahasiswa dalam Pembelajaran

\begin{tabular}{lcccc}
\hline \multicolumn{1}{c}{$\begin{array}{c}\text { Komponen } \\
\text { Keaktifan }\end{array}$} & \multicolumn{2}{c}{ Sebelum Perlakuan } & \multicolumn{2}{c}{ Setelah Perlakuan } \\
Jumlah & Persentase & Jumlah & Persentase \\
\hline $\begin{array}{l}\text { Menyampaikan } \\
\text { pertanyaan }\end{array}$ & 6 & 11 & 12 & 22 \\
$\begin{array}{l}\text { Menyampaikan } \\
\text { pendapat/ide }\end{array}$ & 3 & 5 & 8 & 15 \\
& & & &
\end{tabular}

$\begin{array}{lllll}\begin{array}{l}\text { Menjawab } \\ \text { pertanyaan }\end{array} & 5 & 9 & 12 & 22 \\ \text { individu } & & & \\ \begin{array}{l}\text { Berbagi } \\ \text { informasi dengan } \\ \text { teman sejawat }\end{array} & 5 & 9 & 8 & 15 \\ \begin{array}{l}\text { Keberanian } \\ \text { mencoba } \\ \text { (menggunakan }\end{array} & 3 & 5 & 15 & 27 \\ \text { media) } & & & & \\ \end{array}$

Penggunaan media pembelajaran simulator basic pneumatic pada kompetensi dasar katup kontrol dan katup kerja mempunyai dampak positif terhadap hasil belajar mahasiswa sesuai dengan data yang terdapat pada tabel 1 . Kondisi tersebut karena dengan menggunakan media simulator mahasiswa dapat secara langsung memperagakan atau mencoba mekanisme kerja katup kontrol dan katup kerja. Simulator tersebut juga bersifat manipulatif artinya katup kontrol dan katup kerja dapat diganti sesuai dengan jenis-jenis katup seperti $2 / 2,3 / 2,4 / 2,4 / 3$. Pada saat mahasiswa menggunakan simulator tersebut mahasiswa akan memperoleh pengalaman belajar secara langsung tanpa harus membanyangkan tentang cara kerja katup kontrol dan katup kerja pada sistem pneumatik hidrolik. Disisi yang lain, karena simulator tersebut dilengkapi dengan beberapa jenis katup kontrol yang dapat dirangkai dan dilepas maka akan dapat menstimulus minat mahasiswa untuk mencoba-coba secara langsung.

\section{KESIMPULAN}

Berdasarkan hasil penelitian dan pembahasan dapat disimpulkan penggunaan media pembelajaran dalam bentuk simulator basic pneumatik memiliki pengaruh yang positif terhadap kualitas perkuliahan pada mata kuliah Pneumatik Hidrolik. Meningkatnya kulaitas perkuliahan ditunjukkan dengan dua hal yaitu hasil belajar dan keaktifan mahasiswa dalam proses pembelajaran/perkuliahan.

\section{DAFTAR PUSTAKA}

Arends, 1997. Clasroom Instruction and Management. McGraw-Hill Companies. Inc. New York.

Dahar, R.W, 1988. Teori-teori Belajar. Depdikbud P2LPTK, Jakarta

Gerlach, V.G. dan Ely, D.P. 1971. Teaching and Media. A. Systematic Approach. Englewood Cliffs: Prentice-Hill, Inc.

Hamalik, Oemar. 1994. Media Pendidikan. (Cetakan ke-7). Bandung : Penerbit PT. Citra Aditya Bakti. Sudjana, N. dan Rivai, A. 1990. Media Pembelajaran. Bandung : Penerbit C.V. Sinar Baru Bandung. Supriatna, D, 2009. Pengenalan Media Pembelajaran: Bahan Ajar untuk Diklat E-Training PPPPTK TK dan PLB. Jakarta 